\title{
Correlation between Knowledge and Attitude to the Behavior of Health Workers Regarding Acceptance of Human Milk Bank in General Hospital Dr. Soetomo Surabaya
}

\author{
Rabiatul Adawiah ${ }^{1 *}$, Martono Tri Utomo ${ }^{1,2}$, Kartika Darma Handayani, ${ }^{1,2}$, \\ Dina Angelika ${ }^{1,2}$, Risa Etika ${ }^{1,2}$ \\ ${ }^{1}$ Department of Child Health, Faculty of Medicine Universitas Airlangga \\ 60132, Surabaya, East Java, Indonesia \\ ${ }^{2}$ Dr. Soetomo General Hospital, 60286, Surabaya, East Java, Indonesia
}

*Corresponding author details: Rabiatul Adawiah; rabiatuladawiah.dr@gmail.com

\begin{abstract}
Introduction: Breast milk is a liquid secreted by the mother's breast glands and is useful for the baby. The World Health Organization (WHO) and the American Academy of Pediatrics (AAP) stated that the best alternative for breast milk is donor human milk (DHM). Until now, there is no donor HMB in Indonesia. This study aims to determine the relationship between knowledge and attitudes with the behavior of health workers regarding the acceptance of Human Milk Banks (HMB).

Methods: An analytical cross-sectional study involved health workers at the pediatric ward of General Hospital Dr. Soetomo in 2020. The study involved 77 subjects consisting of doctors and nurses. Data were collected by questionnaires. A multiple linear regression test was used to determine the correlation between knowledge and attitudes with the behavior of health workers regarding the acceptance of HMB.

Results: Among 77 research subjects, 42/77 subjects were doctors. 48/77 were female. 31/77 subjects were in the 25-29 years age group. $41 / 77$ subjects were married. $38 / 77$ subjects working period in the profession was 1 5 years. 67/77 subjects were Muslim. Knowledge was associated with the behavior of health workers ( $p=0.003)$, and attitudes were associated with the behavior of the health workers about the acceptance of the HMB $(p=0.008)$, and there was a simultaneous correlation between knowledge and attitude with the behavior of health workers regarding the acceptance of $\mathrm{HMB}(\mathrm{p}=0.000)$.

Conclusion: These findings showed that knowledge and attitudes were associated with the behavior of health workers regarding the acceptance of HMB. There is a simultaneous relationship between the knowledge and attitude with the behavior of health workers about the acceptance of HMB.
\end{abstract}

Keywords: donor human milk; HMB; knowledge; attitude; behavior

\section{INTRODUCTION}

Breast milk is the best food for babies in early life. Breast milk has many health benefits for both full-term babies and premature babies. Compared with formula-fed babies, both term babies and premature babies who are breastfed have a much lower risk of developing various medical problems both early on in life and later on, such as infections, necrotizing enterocolitis (NEC), risk of allergies, obesity, and diabetes. In addition, breast milk is proven to increase intelligence [1]. However, not all mothers can give breast milk to their babies for various

reasons, ranging from the poor physical condition of the baby, the death of the baby's mother, the mother's unsupportive health condition, and the risk of disease transmission between the mother and her baby through breastfeeding contact. WHO states that the best alternative to breast milk itself, is breast milk directly from healthy mothers or donor breast milk from the Human Milk Bank (HMB) [2]. Countries like South Africa and Kenya have established these banks despite facing infectious disease epidemics such as HIV, TB, and hepatitis $[3,4,5,6]$. Until now, there is no HMB in Indonesia.
This is mostly influenced by problems of belief and religion in the community, besides it taking a long preparation time to make it happen [7]. The role of health workers is very crucial in the success of this bank. Health workers must provide information about the HMB aimed at the community so that they can obtain information, raise awareness, accept changes in behavior and finally be able to take advantage of the information. While, the expected changes from the information dissemination activities are that aspects of knowledge, attitudes, and behavior move towards the proper concept and way. However, the attitude of health workers, a fragmented system, lack of support for government policies, negative perceptions from mothers and the community, and adverse practices are often obstacles to the success of a HMB $[8,9]$.

\section{MATERIAL AND METHODS}

The design used in this analytical descriptive study is a cross-sectional research design conducted from February to April 2020. The samples in this study were 77 health workers consisting of doctors and nurses who worked in the Pediatric Inpatient Installation of RSUD Dr. Soetomo. The sampling technique used was proportional random sampling. 
The definition of the operational variable, knowledge, is the knowledge possessed by respondents about the benefits of breastfeeding and breast milk donors. The knowledge measurement results: Good ( $\geq 80 \%)$, Average $(60-79 \%)$, Poor $(<60 \%)$. Attitude is the respondent's reaction or response to breast milk donors and breast milk banks. Measuring results: Good ( $\geq 80 \%)$, Poor $(<80 \%)$ Behavior is the action of selecting taken by the respondent in determining their acceptance of the HMB. Measuring results: Good ( $\geq 80 \%)$, Poor $(<80 \%)$.

This study uses a questionnaire as a research instrument. Data analysis includes processing research data by means of data classification, coding, scoring, and analysis of research data including univariate analysis (to describe variables by making a frequency distribution table according to occupation, gender, age, marital status, length of work, religion) and analysis to determine the relationship between the independent variable and the dependent variable using multiple linear regression test with a p-value $<0.05$ declared significant.

\section{RESULTS}

There were 77 health worker subjects. The research subjects consisted of 42 doctors (55\%) and 35 nurses (45\%). Most of them were female, namely 48 subjects $(62 \%)$. The youngest subject was 22 years old, while the oldest was 41 years old, with an average age of $30.4 \pm 4.6$ (years), and as many as 31 subjects (40\%) were in the 2529 year age group. As many as 41 subjects (53\%) marital statuses were married. This study also indicated as many as 38 subjects ( $49 \%$ ) working period was $1-5$ years. Most of the subjects were Muslim, namely 67 subjects (87\%).

Based on the distribution of subjects according to the level of knowledge, most health workers had good knowledge as much as $85 \%$, sufficient knowledge as much as $10 \%$, and only $5 \%$ had poor knowledge. Based on the distribution of subjects according to their attitude, $62 \%$ of health workers had a bad attitude, while the remaining $38 \%$ had a good attitude. Based on the distribution of subjects according to behavior, most health workers had poor acceptance of the HMB, which was $69 \%$, while the remaining $31 \%$ had a good reception.

The relationship between the level of knowledge and the behavior of health workers regarding the acceptance of HMB

TABLE 1: The relationship between the knowledge and behavior of health workers regarding the acceptance of HMB at Dr. Soetomo Hospital Surabaya

\begin{tabular}{|l|c|c|c|c|c|c|c|}
\hline \multirow{2}{*}{ Knowledge } & \multicolumn{4}{|c|}{ HMB Behavior Acceptance } & \multicolumn{2}{c|}{ Total } & \multirow{2}{*}{ p-value } \\
\cline { 2 - 7 } & \multicolumn{2}{|c|}{ Good } & \multicolumn{2}{c|}{ Poor } & \multicolumn{2}{c|}{} \\
\cline { 2 - 7 } & $\mathbf{n}$ & $\mathbf{\%}$ & $\mathbf{n}$ & $\mathbf{\%}$ & $\mathbf{N}$ & $\mathbf{\%}$ & \\
\hline Good & 16 & 25 & 49 & 75 & 65 & 100 & \multirow{2}{*}{0.003} \\
\hline Average & 5 & 62 & 3 & 38 & 8 & 100 & \\
\hline Poor & 3 & 75 & 1 & 25 & 4 & 100 & 100 \\
\hline Total & 24 & 31 & 53 & 69 & 77 & 100 \\
\hline
\end{tabular}

The relationship between the attitude and the behavior of health workers regarding the acceptance of HMB

TABLE 2: The relationship between the attitude and behavior of health workers regarding The acceptance of HMB at Dr. Soetomo Hospital Surabaya

\begin{tabular}{|l|c|c|c|c|c|c|c|}
\hline \multirow{2}{*}{ Attitude } & \multicolumn{4}{|c|}{ HMB Behavior Acceptance } & \multicolumn{2}{c|}{ Total } & \multirow{2}{*}{ p-value } \\
\cline { 2 - 7 } & \multicolumn{2}{|c|}{ Good } & \multicolumn{2}{c|}{ Poor } & \multicolumn{2}{c|}{} \\
\cline { 2 - 7 } & $\mathbf{n}$ & $\mathbf{\%}$ & $\mathbf{n}$ & $\mathbf{\%}$ & $\mathbf{N}$ & $\mathbf{\%}$ & \\
\hline Good & 14 & 48 & 15 & 52 & 29 & 100 & \multirow{2}{*}{0.008} \\
\hline Poor & 10 & 21 & 38 & 79 & 48 & 100 & \\
\hline Total & 24 & 31 & 53 & 69 & 77 & 100 & \\
\hline
\end{tabular}

The relationship of knowledge and attitudes with the behavior of health workers regarding the acceptance of HMB

Based on the data analysis of the relationship of knowledge and attitudes with the behavior of health workers regarding the acceptance of the HMB, it shows that there is a simultaneous relationship between the knowledge and attitudes of the subjects and the behavior of the acceptance of the HMB, this is indicated by a significance value of $p=0.000(p<0.05)$.

\section{DISCUSSION}

In this study, most of the subjects were doctors, namely $55 \%$. Meanwhile, research conducted in Canada showed that most of the subjects were nurses, which was $47 \%$, followed by doctors, which was $43 \%$ [10]. Work is a factor that can affect knowledge because a person can gain experience and knowledge in the work environment, either directly or indirectly. Bad experiences will tend to be forgotten and pleasant experiences will make a very deep impression that will form a positive attitude in life.
In this study, most of the subjects were female (62\%) compared to the male (38\%). A study on the acceptance of HMBs for health workers conducted in Zimbabwe showed that the majority of health workers were women, which was $72 \%$, while for men it was $28 \%$ [11]. According to Sunaryo (2004), a person's behavior is influenced by several factors, one of which is genetic or endogenous factors, genetic factors originating from within the individual, including gender. Men's behavior is based on rational considerations or reason, while women are on emotional grounds. 
The majority of the research subjects were in the 25-29 year age group, as many as 31 subjects (40\%), with the youngest at 22 years old and the oldest 41 years old, with a mean age of $30.4 \pm 4.6$ (years). This result was similar to a study conducted by Karadag et al in 2015 in Turkey which showed that most of the subjects were in the 25-29 year age group, which was $30.8 \%$ [12]. In the psychological or mental aspect, a person's level of thinking becomes more mature with increasing age [13]. Age can affect a person's knowledge and attitudes because someone with a relatively young age has little experience and the level of knowledge is still relatively low because of the age factor. Most of the research subjects were married, as many as $53 \%$. This result is similar to the study

conducted by Karadag et al in Turkey which showed that most of the subjects were married, namely 98.5\% [12]. Someone who is married has a better experience, especially for those who already have children, so their level of knowledge about the benefits of breastfeeding and the benefits of breastfeeding is also better.

This study shows that the longest working period for $49 \%$ of the subjects was 1-5 years, followed by $26 \%$ who had 610 years of work. The length of work is a factor that can affect knowledge because a person can gain experience and knowledge in the work environment [14].

This study shows that most subjects' religion was Islam at $87 \%$, followed by Protestantism at $9 \%$. The majority of the Indonesian population is Muslim, around $87.2 \%$, followed by Protestants around 6.9\%, Catholics around 2.9\%, and Hindus around 1.7\% [15]. Factors that can influence a person's attitudes and behavior are external factors, namely the environment. This environmental factor is the dominant factor that affects a person's behavior, including religion. Religion is a living belief that enters into the construction of a person's personality and influences individual behavior.

Based on data analysis between the level of knowledge and behavior of health workers about the acceptance of HMBs, it was obtained with the value of $p=0.003$, so it could be said that there was a relationship between the level of knowledge and the behavior of health workers about the acceptance of HMBs. Knowledge is crucial in determining a person's behavior because knowledge determines a person's perceptions and habits in everyday life. A high level of knowledge can also affect the mindset of a person or even society from negative to positive because it is based on awareness, interest, and positive attitude considerations [16].

Based on data analysis between the attitude and behavior of health workers about the acceptance of HMBs using multiple linear regression tests, $p$-value $=0.008$, there is a relationship between the attitudes of health workers and the acceptance behavior of HMBs. Attitude is defined as a reaction or response of a person who is still closed to a stimulus or object [17]. Attitude is a willingness to behave in a positive (good) or negative (bad) manner that already involves the mind and emotions concerned. Attitude has an important role concerning a person's behavior in making decisions, including decisions in accepting HMBs. Based on the analysis, it was found that the knowledge and attitudes of health workers and the behavior of utilizing HMBs using multiple linear regression tests obtained pvalue $=0.000$, so there is a simultaneous relationship between the three. According to Green (1980) in Notoatmodjo (2007), a person's behavior is influenced by three main factors, namely: (a). predisposing factors, these factors include knowledge and attitudes of the community towards health, traditions, and beliefs on matters related to health, the value system adopted by the community, the education level, the socioeconomic level, and so on. These factors, especially positive ones, will facilitate the realization of behavior so they are often referred to as facilitation factors

(b). Enabling factors, these factors include the availability of facilities and infrastructure or health facilities for the community. These facilities basically support or enable the realization of health behaviors, so these factors are called supporting factors or enabling factors

(c). Reinforcing factors, these factors include attitudes and behavior factors of community leaders, religious leaders, and the behavior of officers including health workers, as well as laws and government regulations from both central and local governments [13].

\section{CONCLUSIONS}

From this study, it can be concluded that there is a relationship between the knowledge and behavior of health workers about the acceptance of a HMB, there is a relationship between the attitude and behavior of health workers about the acceptance of HMB, and there is a simultaneous relationship between the knowledge and attitude with the behavior of health workers about the acceptance of HMB.

\section{ACKNOWLEDGEMENTS}

The authors thank the Dr. Soetomo General Hospital, Surabaya Indonesia for providing the research facilities.

\section{REFERENCES}

[1] Wagner, J., Hanson, C. dan Anderson Berry, A. Donor Human Milk for Premature Infants. ICAN. 2013;5:7177.

[2] WHO. Acceptable medical reasons for use of breastmilk substitutes. 2009.

[3] Ighogboja IS, Olarewaju RS, Odumodu CU, Okuonghae HO. Mothers' attitudes towards donated breastmilk in Jos, Nigeria. J Human Lactation. 1995; 11:93-6.

[4] Pimenteira Thomaz AC, Maia Loureiro LV, da Silva OT, Furtado Montenegro NC, Dantas Almeida junior E, Fernando Rodrigues Soriano C, et al. The human milk donation experience: motives, influencing factors, and regular donation. J Hum Lact. 2008; 24:69-76.

[5] Coutsoudis I, Petrites A, Coutsoudis A. Acceptability of donated breast milk in a resource limited south African setting. Int Breastfeed 2011; 6:3.

[6] Iloh KK, Osuorah CD, Ndu IK, Asinobi IN, ObumnemeAnyim IN, Ezeudu CE, et al. Perception of donor breast milk and determinants of its acceptability among mothers in a developing community: a crosssectional multi-center study in south-East Nigeria. Int Breastfeed J. 2018; 13:47.

[7] Ulfa, M. 2016. Bank ASI Dilihat dari Sisi Agama serta Kaitannya dengan Hukum Radha'ah. Jakarta: Institut Ilmu Al-Quran. 
[8] Brownell EA, Lussier MM, Herson VC, Hagadorn JI, Marinelli KA. Donor HMB data collection in North America: an assessment of current status and future needs. J Hum Lact. 2014; 30:47 -53.

[9] deMarchis A, Israel-Ballard K, Mansen KA, Engmann C. Establishing an integrated HMBing approach to strengthen newborn care. J Perinatol. 2017; 37:46974.

[10] Michael, G, Antunes M, Shaik S dan Turner J. Health Practitioners Knowledge, Beliefs, and Attitudes Regarding the Use of Donor Human Milk in Neonatal Intensive Care. Matern Child Nutr. 2016; 2:108.

[11] Chagwena, D., Mugariri, F., Sithole, B., Mataga, S. Danda, R dan Matsungo, T. Acceptability of donor breastmilk banking among health workers: a crosssectional survey in Zimbabwean urban settings. Int Breastfeed J. 2020; 15:37.
[12] Karadag, A., Ozdemir, R., Ozer, A., Dogan, D dan Elkiran, 0. 2015. HMBing and milk kinship: Perspectives of mothers in a Muslim country. J Trop Pediatr. 2015; 61:188-96.

[13] Notoatmodjo, S. 2007. Promosi Kesehatan dan Ilmu Perilaku. Jakarta: Rineka Cipta.

[14] Sepang, F., Gunawan, S. dan Pateda, V. 2013. FaktorFaktor yang Berhubungan dengan Tingkat Pengetahuan Tentang Leukemia Anak Pada Petugas Kesehatan Puskesmas Manado. Universitas Sam Ratulangi.

[15] Portal Informasi Indonesia. 2021. Profil Agama Indonesia.

[Available from: https://indonesia.go.id/profil/agama]

[16] Notoatmodjo, S. 2013. Pendidikan dan Perilaku dan Ilmu Perilaku. Jakarta: Rineka Cipta.

[17] Notoatmodjo, S. 2005. Metodologi Penelitian Kesehatan. Jakarta: Rineka Cipta. 